\title{
Scoliosis in adolescents reduces the risk of eating disorders
}

\author{
F Zaina ${ }^{1 *}$, S Donzelli ${ }^{1}$, M Lusini ${ }^{2}$, M Togoingar ${ }^{3}$, V Negro $^{3}$, S Negrini ${ }^{1}$ \\ From 8th International Conference on Conservative Management of Spinal Deformities and SOSORT 2011 \\ Annual Meeting \\ Barcelona, Spain. 19-21 May 2011
}

\section{Background and purpose}

A recent study suggests a correlation between idiopathic scoliosis in adolescence and eating disorders [1]. Nevertheless, this did not correspond to our clinical experience in this same population. The aim of this study was to verify the correlation between scoliosis and eating disorders in adolescence.

\section{Materials and methods}

Design: cross-sectional study.

Population: 187 consecutive adolescent girls with idiopathic scoliosis (mean Cobb angle $26^{\circ}$, range $11-73^{\circ}$, age $15.2 \pm 2.5$; $24 \%$ juveniles, $76 \%$ adolescent type); 93 school girl controls (age 14.9 \pm 1.0 ).

All the subjects answered the Italian validated questionnaire EAT-26 about eating habitude in order to retrieve eating disorders. BMI was calculated for all subjects and compared to reference data.

Statistical Analysis: chi-square test and ANOVA. of eating disorders in female scoliosis patients than in the general population (both our own controls and Italian reference values). This contrast with some expert opinions and a recent study performed in Italy. The low BMI already reported in the literature as typical of scoliosis subjects is confirmed by our data.

Author details

${ }^{1}$ ISICO Milan, Italy. ${ }^{2}$ Siena University, Italy. ${ }^{3}$ Università Cattolica del Sacro Cuore di Milano, Italy.

Published: 27 January 2012

\section{Reference}

1. Alborghetti A, Scimeca G, Costanzo G, Boca S: The prevalence of eating disorders in adolescents with idiopathic scoliosis. Eat Disord 2008, 16(1):85-93.

doi:10.1186/1748-7161-7-S1-O7

Cite this article as: Zaina et al:: Scoliosis in adolescents reduces the risk of eating disorders. Scoliosis 2012 7(Suppl 1):07.

\section{Results}

Only 3 (1.6\%; IC95 -0.2/3.4\%) subject in the scoliosis group showed EAT-26 scores suggestive for eating disorders versus 7 (7.5\%; IC95\% 2.2/12.9\%) in the school population; the difference was statistically significant $(\mathrm{p}<0.05)$. The odds ratio of eating disorders in adolescents with scoliosis is 0.2 (IC95-1.18/1.58). BMI was slightly lower $(\mathrm{p}<0.05)$ for scoliosis patients $(19 \pm 0.2)$ that for school girls $(21 \pm 0.3)$.

\section{Conclusions}

EAT-26 is recognised among the most valid questionnaires for eating disorders and has been widely applied in various countries. Applying it, we found a lower incidence

Submit your next manuscript to BioMed Central and take full advantage of:

- Convenient online submission

- Thorough peer review

- No space constraints or color figure charges

- Immediate publication on acceptance

- Inclusion in PubMed, CAS, Scopus and Google Scholar

- Research which is freely available for redistribution

Submit your manuscript at www.biomedcentral.com/submit
() Biomed Central

\section{Biomed Central}

(c) 2012 Zaina et al; licensee BioMed Central Ltd. This is an open access article distributed under the terms of the Creative Commons Attribution License (http://creativecommons.org/licenses/by/2.0), which permits unrestricted use, distribution, and reproduction in any medium, provided the original work is properly cited. 